\title{
Review
}

\section{Synthesis of lamp phosphors: facile combustion approach}

\author{
S. Ekambaram ${ }^{\mathrm{a}, *}$, K.C. Patil ${ }^{\mathrm{b}}$, M. Maaza ${ }^{\mathrm{c}}$ \\ a Purdue University, Forney Hall of Chemical Engineering, 480 Stadium, Mall Drive, West Lafayette, IN 47907, USA \\ ${ }^{\mathrm{b}}$ Inorganic and Physicas Chemistry Department, Indian Institute of Science, Bangalore-12, India \\ ${ }^{c}$ School of Physics, University of Witwatersrand, Johannesburg, South Africa
}

\begin{abstract}
This review article is intended to show feasibility of solution combustion process for the synthesis of rare-earth activated insulating materials at low temperature $\left(350-500^{\circ} \mathrm{C}\right)$ and in a very short time $(<5 \mathrm{~min})$. Thus, this review starts with combustion synthesis followed by luminescent properties of combustion synthesized tricolour lamp phosphors. Major focuses in red phosphors are effect of calcinations and of impurities on luminescence of $\mathrm{Eu}^{3+}$ activated red phosphors. In the $\mathrm{Eu}^{2+}$ activated blue phosphor section, effect of activator concentration $\left(\mathrm{Eu}^{2+}\right)$ and concentration of $\mathrm{BaO}$ in $\mathrm{BaO} \cdot 6 \mathrm{Al}_{2} \mathrm{O}_{3}$ are studied. In the case of green phosphors, co-doping of $\mathrm{Eu}^{2+}, \mathrm{Ce}^{3+}$ and $\mathrm{Tb}^{3+}$ in $\mathrm{LaMgAl}_{11} \mathrm{O}_{19}$ is investigated.
\end{abstract}

Keywords: Combustion; Low temperature; Lamp phosphors

\section{Contents}

1. Introduction .

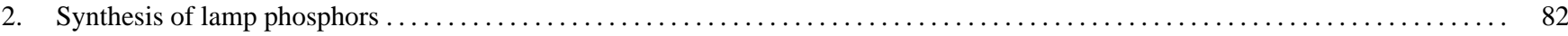

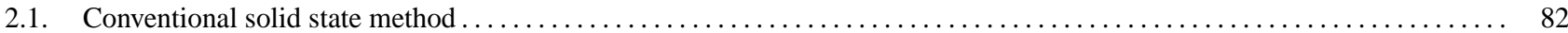

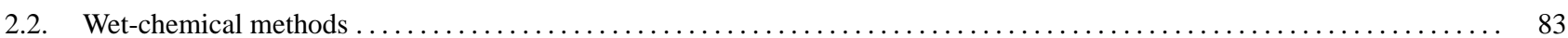

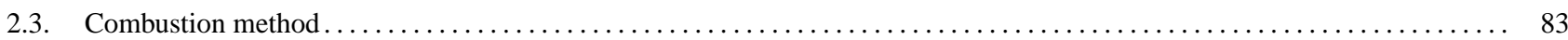

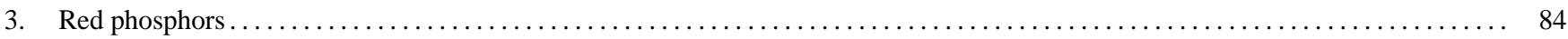

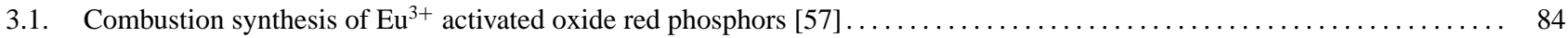

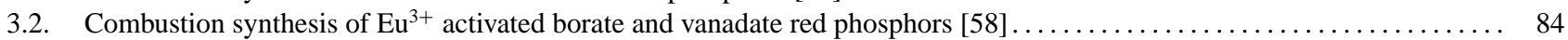

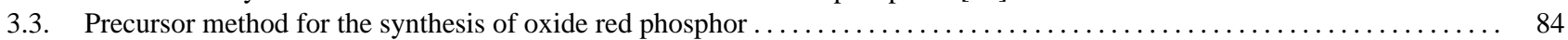

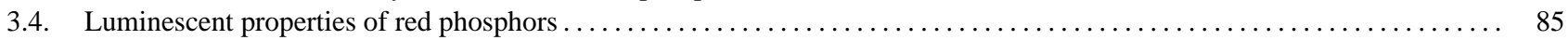

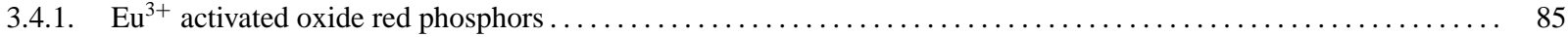

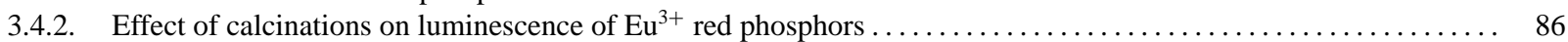

3.4.3. Effect of impurity ions on luminescence of $\mathrm{Eu}^{3+}$ activated red phosphors $\ldots \ldots \ldots \ldots \ldots \ldots \ldots \ldots \ldots \ldots \ldots \ldots$

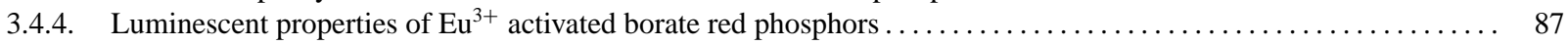

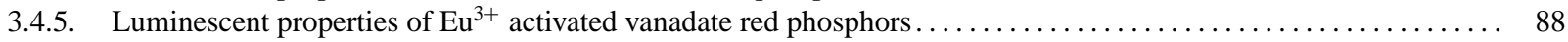

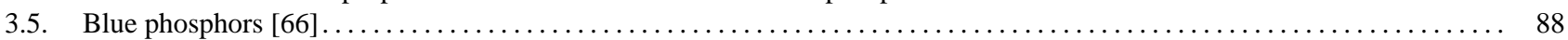

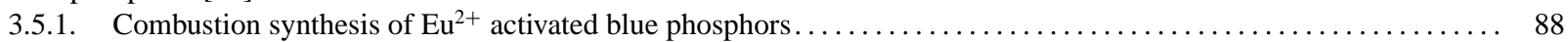

3.5.2. Luminescent properties of $\mathrm{Eu}^{2+}$ activator blue phosphors $\ldots \ldots \ldots \ldots \ldots \ldots \ldots \ldots \ldots \ldots \ldots \ldots \ldots \ldots \ldots \ldots \ldots$

\footnotetext{
* Corresponding author. Tel.: +1 765496 6120; fax: +1 7654944050 .

E-mail address: s_ekambaram69@hotmail.com (S. Ekambaram).
} 


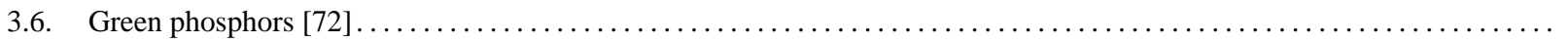

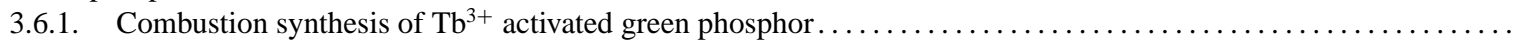

3.6.2. Luminescent properties of $\mathrm{Tb}^{3+}$ activated green phosphors $\ldots \ldots \ldots \ldots \ldots \ldots \ldots \ldots \ldots \ldots \ldots \ldots \ldots \ldots \ldots$

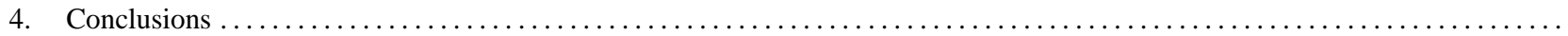

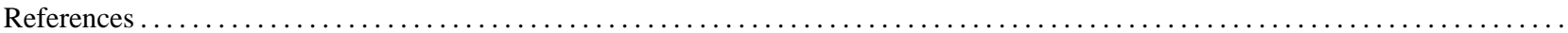

\section{Introduction}

Phosphor materials find wide applications ranging from fluorescent lamp to luminescence immunoassay [1]. These materials essentially convert one type of energy into visible radiation and hence, phosphor materials are called optical transducer. They are generally crystalline in nature. Since, the theme of this review article is focused on lamp phosphors, we will be concentrating on phosphor materials used in tricolour lamp. In the fluorescent lamp, phosphor materials convert UV radiation into visible radiation. Lamp phosphors are mostly white in colour and they should not absorb the visible radiation.

Fluorescent lamp is made of glass tube sealed with two ends in which noble gas and $\mathrm{Hg}$ vapour are present in 400 and $0.8 \mathrm{~Pa}$ pressure, respectively [1]. About $11.5 \mathrm{mg}$ of $\mathrm{Hg}$ is used in fluorescent lamp of diameter $30 \mathrm{~mm}$. In the electric discharge $\mathrm{Hg}$ atoms are excited to higher energy levels. When they return to ground state it emits $85 \%$ $254 \mathrm{~nm}$ wave length, $12 \% 185 \mathrm{~nm}$ and $3 \%$ in the visible radiation. Phosphor materials coated inside the tube essentially convert 254 and $185 \mathrm{~nm}$ wavelengths into visible radiation. Thickness of phosphor materials coated inside the tube is in the order of $20-40 \mu \mathrm{m}$. Since phosphors have direct contact with $\mathrm{Hg}$, potential phosphors such as $\mathrm{ZnS}$ can not be used because of reaction between $\mathrm{Hg}$ and $\mathrm{ZnS}$. Therefore, oxides are used as the hosts for fluorescent lamps.

There are three types of fluorescent lamps available currently and these are halophosphate lamp, tricolour lamp and special de luxe lamp [2]. Among them, tricolour lamp phosphors form a special group. The tricolour lamp phosphors are 60 wt. $\% \mathrm{Y}_{2} \mathrm{O}_{3}: \mathrm{Eu}^{3+}, 30$ wt. $\% \mathrm{CeMgAl}_{11} \mathrm{O}_{19}: \mathrm{Tb}^{3+}$ and 10 wt. $\% \mathrm{BaMgAl}_{10} \mathrm{O}_{17}: \mathrm{Eu}^{2+}$, where, $\mathrm{Eu}^{3+}, \mathrm{Eu}^{2+}$ and $\mathrm{Tb}^{3+}$ are activators. In the case of green, non-radiative energy, transfer goes directly from $\mathrm{Ce}^{3+}$ to $\mathrm{Tb}^{3+}$ and hence, lot of cerium and terbium oxides are required. Therefore, this green phosphor has been replaced by other two green phosphors, viz. $(\mathrm{La}, \mathrm{Ce}) \mathrm{PO}_{4}: \mathrm{Tb}^{3+}$ and $(\mathrm{Ce}, \mathrm{Gd}) \mathrm{MgB}_{5} \mathrm{O}_{10}: \mathrm{Tb}^{3+}$. In these newly developed phosphors, $\mathrm{Tb}^{3+}$ is activated via energy migration in the $\mathrm{Ce}^{3+}$ and $\mathrm{Gd}^{3+}$ sublattice, respectively. Thus, concentration of terbium oxide is reduced and hence, cost of the phosphor is improved [3]. Because of improved lumen output and greater radiation stability of tricolour lamp phosphors over conventional lamp phosphor (linear fluorescent), diameter of the fluorescent lamp could be reduced to $10 \mathrm{~mm}$ from $38 \mathrm{~mm}$. This innovation results in Hi-Tech compact fluorescent lamps with various sizes and shapes.
There has been an increasing interest in rare-earth phosphors since 1980 as evidenced from the number of international conferences held [4-8], technical reports [9-24] and reviews [25-35] published. Phosphors activated by rare earth ions exhibit some peculiarities. In the energy level diagram of the rare-earth, luminescence processes often correspond to electronic transitions within the incompletely filled $4 \mathrm{f}$ shell, which is extensively shielded from host lattice [2]. Consequently, these phosphors have narrow band spectra which are to a great extent independent of the nature of the host lattice. Because of the low interaction with the crystal field, luminescence quantum yield of phosphors activated with rare earths is often high compared to other phosphors. Quenching occurs only at higher temperatures or higher activator concentrations. Europium (II and III) and terbium are of interest as activators for getting tricolour lamp phosphors.

\section{Synthesis of lamp phosphors}

\subsection{Conventional solid state method}

The fluorescent lamps are coated with phosphor by using a suspension of phosphor powder particles. A lamp phosphor is, therefore, needed as a powder. The luminescent activator concentration is of the order of 1-3\% (atom percent). Therefore, high quality starting materials and a clean production process are prerequisite for obtaining luminescent materials with a high efficiency.

Because of refractory nature of alumina and rare-earth oxides, conventional synthesis of lamp phosphors requires temperature greater than $1000^{\circ} \mathrm{C}$. Thus, corresponding metal oxides/carbonates are ground well and heated $>1000^{\circ} \mathrm{C}$. The mechanism of solid state reactions is diffuse control reaction and hence, repeated grinding and repeated heating are required [36-44]. The controlled atmosphere is necessary to master the valence of the activator (for example $\mathrm{Eu}^{2+}$ or $\mathrm{Eu}^{3+}$ ) and the stoichiometry of the host lattice. Therefore, doping $1-3 \%$ of activator in oxide host has been delicate. For example, preparation of $\mathrm{Tb}^{3+}$ activated $\mathrm{CeMgAl}_{11} \mathrm{O}_{19}$ green phosphor has been achieved from a mixture of $\mathrm{Al}_{2} \mathrm{O}_{3}, \mathrm{MgCO}_{3}$, $\mathrm{CeO}_{2}$ and $\mathrm{Tb}_{4} \mathrm{O}_{7}$ at $1500^{\circ} \mathrm{C}, 5 \mathrm{~h}$ with small quantities of $\mathrm{MgF}_{2}$ or $\mathrm{AlF}_{3}$ as a crystallizing agent [41].

Limitations in synthesis of lamp phosphors by conventional solid state method.

Preparation of single phase compound is difficult by the conventional solid state method. Hence, doping a low con- 
centration (of the order of 1-3\%) of activator has always been delicate. Thus, the limitations of conventional solid state method are

1. Inhomogeneity of the product.

2. Formation of large particles with low surface area and hence, mechanical particle size reduction is required, which introduces impurity and defects.

3. Presence of defects, which are harmful to luminescence.

The problem of inhomogeneity could be mitigated by the use of non-conventional methods (wet-chemical).

\subsection{Wet-chemical methods}

Wet-chemical techniques are now available for simple oxide phosphor synthesis such as $\mathrm{Eu}^{3+}$ activated $\mathrm{Y}_{2} \mathrm{O}_{3}$ red phosphor. These techniques $[45,46]$ are defined as techniques which do not comprise of the normal mixing, calcinations and grinding operations. Wet-chemical methods such as coprecipitation [47], sol-gel [48,49], hydrothermal [50], evaporative decomposition [51], reverse micellar [52,53], surface modifier [54] etc. have been employed to synthesize rareearth activated lamp phosphors. These wet-chemical methods dope rare earth activators uniformly. But, calcination is required to get crystalline (required) phosphors. However, to my knowledge, wet-chemical techniques are not available for the synthesis of complex oxide phosphors (blue and green phosphors). Therefore, we would like to emphasise importance of solution combustion process, for the synthesis of both simple and complex oxide phosphors. In the following section, we deal with solution combustion synthesis and luminescent properties of rare-earth activated lamp phosphors.

\subsection{Combustion method}

Combustion method [55,56] is yet another wet-chemical method which does not require further calcinations and repeated heating. This method was accidentally discovered in 1988 in Prof. Patil's lab in India. It is an exothermic reaction and occurs with the evolution of heat and light. Such a high temperature leads to formation and crystallization of phosphor materials.

For any combustion, fuel and oxidizer are required. When the mixture of fuel and oxidizer are ignited, combustion takes place. For the combustion synthesis of oxides, metal nitrates are used as oxidizer, and fuels employed are hydrazine based compounds or urea or glycine. Stoichiometric compositions of metal nitrates and fuels are calculated based upon propellant chemistry. Thus, heat of combustion is maximum for $\mathrm{O} / \mathrm{F}$ ratio 1 [55]. Based on the concepts used in propellant chemistry [55], the elements $\mathrm{C}, \mathrm{H}, \mathrm{V}, \mathrm{B}$ or any other metal are considered as reducing elements with valencies $4+, 1+, 5+, 3+$ (or valency of the metal ion in that compound), respectively and oxygen is an oxidizer having the valency of $2-$. The valency of nitrogen is taken as zero because of its conversion to molecular nitrogen during combustion. Accordingly, the oxidizing (O) and reducing (F) valencies for $\mathrm{M}\left(\mathrm{NO}_{3}\right)_{3}$ and oxalyl dihydrazide can be calculated as follows.

$$
\begin{aligned}
& \mathrm{M}\left(\mathrm{NO}_{3}\right)_{3} \\
& 1 \mathrm{M}=3+ \\
& 9 \mathrm{O}=18- \\
& 3 \mathrm{~N}=0
\end{aligned}
$$

$15-$

where, $\mathrm{M}=\mathrm{Y}, \mathrm{Gd}, \mathrm{La}, \mathrm{Al}, \mathrm{Tb}, \mathrm{Ce}$.

Oxalyl dihydrazide, $\mathrm{C}_{2} \mathrm{H}_{6} \mathrm{~N}_{4} \mathrm{O}_{2}(\mathrm{ODH})$

$2 \mathrm{C}=8+$

$6 \mathrm{H}=6+$

$2 \mathrm{O}=4-$

$4 \mathrm{~N}=0$

$10+$

The oxidizing and reducing valencies of metal nitrates and fuels used in the combustion synthesis of oxide phosphors are summarized in Table 1. Thus, the stoichiometry for the preparation of $\mathrm{Ln}_{2} \mathrm{O}_{3}$ where $\mathrm{Ln}=\mathrm{Y}, \mathrm{La}$ and $\mathrm{Gd}$ from $\mathrm{Ln}\left(\mathrm{NO}_{3}\right)_{3}: \mathrm{ODH}$ becomes 1:1.5.

The preparation of ytrria using yttrium nitrate and oxalyl dihydrazide $(\mathrm{ODH})$ redox mixture is described below as a representative of all phosphors.

Yttrium nitrate $(11.493 \mathrm{~g}, 0.03 \mathrm{~mol})$ and oxalyl dihydrazide $(5.314 \mathrm{~g}, 0.045 \mathrm{~mol})$ were dissolved in a minimum amount of water in a pyrex dish $(100 \mathrm{~mm} \times 50 \mathrm{~mm})$. The pyrex dish was introducted into a muffle furnace $(l=28 \mathrm{~cm}$, $b=17 \mathrm{~cm}$ and $h=7 \mathrm{~cm}$ ) maintained at $400^{\circ} \mathrm{C}$. The solution boils, foams and ignites to burn with flame to yield voluminous, foamy yttria. Flame temperature measured by an optical pyrometer was $1400^{\circ} \mathrm{C} \pm 100^{\circ} \mathrm{C}$. The entire combustion process lasted for about $5 \mathrm{~min}$. The combustion process is self-propagating i.e., once ignited it goes to completion without the supply of additional heat from an external source.

Table 1

Oxidizing and reducing valencies of metal nitrates and fuels

\begin{tabular}{lc}
\hline Compound & $\begin{array}{c}\text { Oxidizing/Reducing } \\
\text { valency }\end{array}$ \\
\hline $\mathrm{M}\left(\mathrm{NO}_{3}\right)_{2}$ & $10-$ \\
$\left.\mathrm{M}_{2} \mathrm{NO}_{3}\right)_{3}$ & $15-$ \\
$\left.\mathrm{M} \mathrm{NO}_{3}\right)_{4}$ & $20-$ \\
$\mathrm{NH}_{4} \mathrm{NO}_{3}$ & $2-$ \\
Urea, $\mathrm{CH}_{4} \mathrm{~N}_{2} \mathrm{O}$ & $6+$ \\
Carbohydrazide $(\mathrm{CH}), \mathrm{CH}_{6} \mathrm{~N}_{4} \mathrm{O}_{2}$ & $8+$ \\
Oxalyl dihydrazide $(\mathrm{ODH}), \mathrm{C}_{2} \mathrm{H}_{6} \mathrm{~N}_{4} \mathrm{O}_{2}$ & $10+$ \\
3-Methyl Pyrazole 5-One $\left(3 \mathrm{MP}_{2} \mathrm{O}\right), \mathrm{C}_{4} \mathrm{H}_{6} \mathrm{~N}_{2} \mathrm{O}$ & $20+$ \\
Diformyl hydrazine (DFH), $\mathrm{C}_{2} \mathrm{H}_{4} \mathrm{~N}_{2} \mathrm{O}_{2}$ & $8+$ \\
Y( $\left.\mathrm{N}_{2} \mathrm{H}_{3} \mathrm{COO}\right)_{3}$ & $12+$ \\
$\mathrm{NH}_{4} \mathrm{VO}_{3}$ & $3+$ \\
\hline
\end{tabular}




\section{Red phosphors}

Activator used for red phosphor is $\mathrm{Eu}^{3+}\left(4 \mathrm{f}^{6}\right)$ and the commonly used hosts are $\mathrm{Y}_{2} \mathrm{O}_{3}, \mathrm{Gd}_{2} \mathrm{O}_{3}, \mathrm{YVO}_{4}$ and $\mathrm{LnBO}_{3}$, $\mathrm{Ln}=\mathrm{La}, \mathrm{Gd}$ and $\mathrm{Y}$.

\subsection{Combustion synthesis of $\mathrm{Eu}^{3+}$ activated oxide red phosphors [57]}

For the combustion synthesis of these phosphors, the appropriate metal nitrate, europium nitrate and fuel, either ODH or urea were used. When ODH was used as the fuel, the combustion was flaming and the flame temperature measured using optical pyrometer was about $1400^{\circ} \mathrm{C} \pm 100^{\circ} \mathrm{C}$. But, combustion behaviour was smouldering (without flame) when urea was employed in the combustion process. Theoretical equation assuming complete combustion may be written for $\mathrm{Eu}^{3+}$ activated $\mathrm{Y}_{2} \mathrm{O}_{3}$ red phosphor using $\mathrm{ODH}$ as the fuel as follows.

$$
\begin{aligned}
& 2-x \mathrm{Y}\left(\mathrm{NO}_{3}\right)_{3}+x \mathrm{Eu}\left(\mathrm{NO}_{3}\right)_{3}+3 \mathrm{C}_{2} \mathrm{H}_{6} \mathrm{~N}_{4} \mathrm{O}_{2}(\mathrm{ODH}) \\
& \rightarrow Y_{2-x} \mathrm{Eu}_{x} \mathrm{O}_{3}(s)+\text { by products }
\end{aligned}
$$

where $x=0.05$.

Fig. 1 shows powder $\mathrm{XRD}$ of $\mathrm{Eu}^{3+}$ doped $\mathrm{Y}_{2} \mathrm{O}_{3}$ red phosphor synthesized by ODH and urea methods. It is clear that ODH process shows very sharp powder XRD pattern and urea process exhibits very broad powder XRD peaks. Therefore, by changing the fuel one can control particulate properties (Specific surface areas $=22$ and $13 \mathrm{~m}^{2} / \mathrm{g}$ for urea and ODH processes).

\subsection{Combustion synthesis of $\mathrm{Eu}^{3+}$ activated borate and vanadate red phosphors [58]}

For the combustion synthesis of borate red phosphors, aqueous solution of $\mathrm{Ln}\left(\mathrm{NO}_{3}\right)_{3}, \mathrm{H}_{3} \mathrm{BO}_{3}$ and $\mathrm{ODH}$ was heated at $400{ }^{\circ} \mathrm{C}$ in air. Boric acid is a neutral compound and hence, neither extra ammonium nitrate nor fuel was required. Whereas, ammonium meta vanadate was used as source for vanadium in the vanadate red phosphor preparation. There-

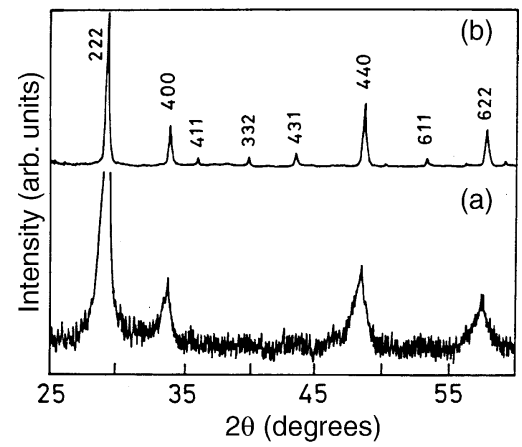

Fig. 1. Powder XRD patterns of combustion synthesized $\mathrm{Y}_{2} \mathrm{O}_{3}: \mathrm{Eu}^{3+}$ (a) urea process, and (b) ODH process.

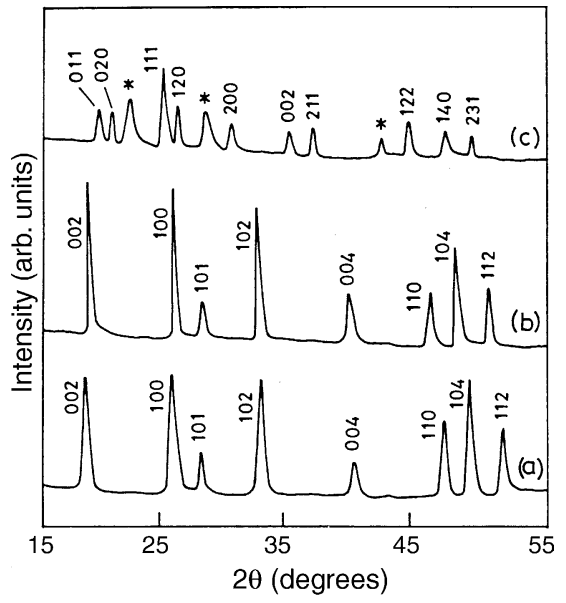

Fig. 2. Powder XRD patterns of combustion prepared $\mathrm{LnBO}_{3}(\mathrm{ODH}$ process) (a) $\mathrm{Ln}=\mathrm{Y}$, (b) $\mathrm{Ln}=\mathrm{La}$ and (c) $\mathrm{Ln}=\mathrm{Gd}$, where $*$ monoclinic $\mathrm{GdBO}_{3}$.

fore, ammonium meta vanadate served as reducer and hence, completely decomposable ammonium nitrate was used as oxidizer. Formation of borate and vanadate by combustion may be represented by the following reactions.

$$
\begin{aligned}
& 2 \mathrm{Ln}\left(\mathrm{NO}_{3}\right)_{3}+\underset{(\mathrm{ODH})}{3 \mathrm{C}_{2} \mathrm{H}_{6} \mathrm{~N}_{4} \mathrm{O}_{2}} \rightarrow \mathrm{Ln}_{2} \mathrm{O}_{3}(s)+\text { by product } \\
& 4 \mathrm{Ln}\left(\mathrm{NO}_{3}\right)_{3}+\underset{(3 \mathrm{MP5O})}{3 \mathrm{C}_{4} \mathrm{H}_{6} \mathrm{~N}_{2} \mathrm{O}} \rightarrow 2 \mathrm{Ln}_{2} \mathrm{O}_{3}(s)+\text { by product } \\
& 2 \mathrm{H}_{3} \mathrm{BO}_{3} \rightarrow \mathrm{B}_{2} \mathrm{O}_{3}(s)+3 \mathrm{H}_{2} \mathrm{O}(\mathrm{g}) \\
& 2 \mathrm{NH}_{4} \mathrm{VO}_{3}+3 \mathrm{NH}_{4} \mathrm{NO}_{3} \rightarrow \mathrm{V}_{2} \mathrm{O}_{5}(s)+\text { by product }
\end{aligned}
$$

The products formed $\mathrm{Ln}_{2} \mathrm{O}_{3}, \mathrm{~B}_{2} \mathrm{O}_{3}, \mathrm{~V}_{2} \mathrm{O}_{5}$ further react to give corresponding metal borates and metal vanadate. Fig. 2 shows the powder XRD patterns of as-prepared $\mathrm{LnBO}_{3}(\mathrm{Ln}=\mathrm{La}, \mathrm{Gd}$ and $\mathrm{Y})(\mathrm{ODH}$ fuel). It reveals that except for $\mathrm{GdBO}_{3}$, other borates are single phase crystalline compounds. Thermal evolution of $\mathrm{GdBO}_{3}$ was carried out using powder XRD. Fig. 3 shows the powder XRD patterns of asprepared and calcined $\mathrm{GdBO}_{3}$. It indicates that single phase $\mathrm{GdBO}_{3}$ could be obtained by calcining it at $900^{\circ} \mathrm{C}$ for $1 \mathrm{~h}$. Asformed $\mathrm{YVO}_{4}$ (3-methyl-pyrazole-5-one, $\mathrm{C}_{4} \mathrm{H}_{6} \mathrm{~N}_{2} \mathrm{O} 3 \mathrm{MP5O}$ process) was $\mathrm{X}$-ray amorphous which on heating at $650{ }^{\circ} \mathrm{C}$ for $1 \mathrm{~h}$ showed crystalline phase (Fig. 4). The amorphous yttrium vanadate could be crystallized to single phase material at $650{ }^{\circ} \mathrm{C}$ compared to $>1000^{\circ} \mathrm{C}$ required in the ceramic method [59]. The low calcinations temperature required to form the desired phase may be attributed to the formation of fine and reactive $\mathrm{Y}_{2} \mathrm{O}_{3}$ and $\mathrm{V}_{2} \mathrm{O}_{5}$ powders in the combustion process.

\subsection{Precursor method for the synthesis of oxide red phosphor}

$\mathrm{Eu}^{3+}$ activated red phosphor was also synthesized from redox compound/fuel rich compound or in other words, valency of the compound is positive and hence, it is 


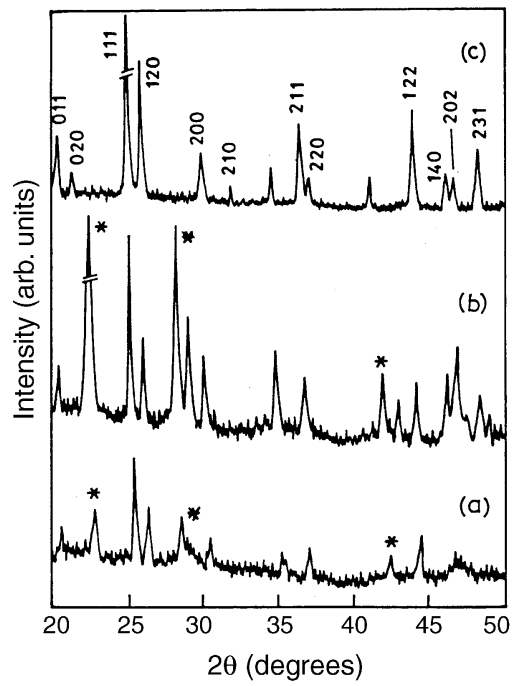

Fig. 3. Powder XRD patterns of $\mathrm{GdBO}_{3}: \mathrm{Eu}^{3+}$ (a) as-prepared, (b) $700{ }^{\circ} \mathrm{C}$, and (c) $900^{\circ} \mathrm{C}$, where * monoclinic $\mathrm{GdBO}_{3}$.

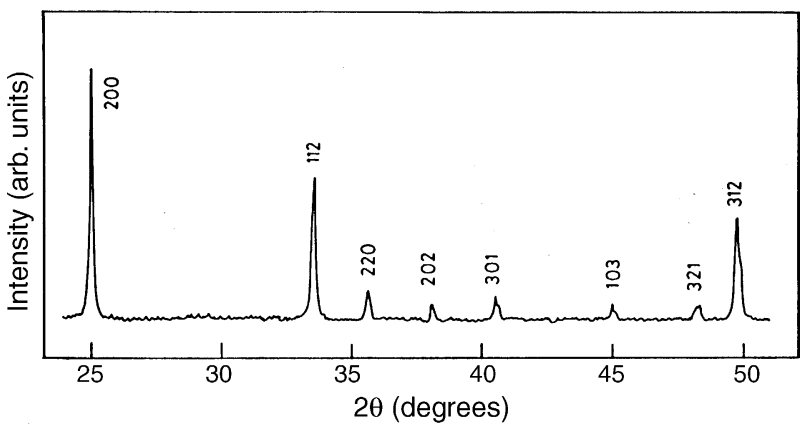

Fig. 4. Powder XRD of heat treated at $650{ }^{\circ} \mathrm{C} \mathrm{YVO}_{4}: \mathrm{Eu}^{3+}$ red phosphor (3MP5O process).

called fuel containing $\mathrm{Eu}^{3+}$ and $\mathrm{Y}^{3+}$. $\mathrm{Eu}^{3+}$ and $\mathrm{Y}^{3+}$ form the following compounds with hydrazine carboxylate ligand $\left(\mathrm{N}_{2} \mathrm{H}_{3} \mathrm{COON}_{2} \mathrm{H}_{5}\right), \mathrm{Y}\left(\mathrm{N}_{2} \mathrm{H}_{3} \mathrm{COO}\right)_{3} \cdot 3 \mathrm{H}_{2} \mathrm{O}$ and $\mathrm{Eu}\left(\mathrm{N}_{2} \mathrm{H}_{3} \mathrm{COO}\right)_{3} \cdot 3 \mathrm{H}_{2} \mathrm{O}$. Powder XRD patterns (Fig. 5) of

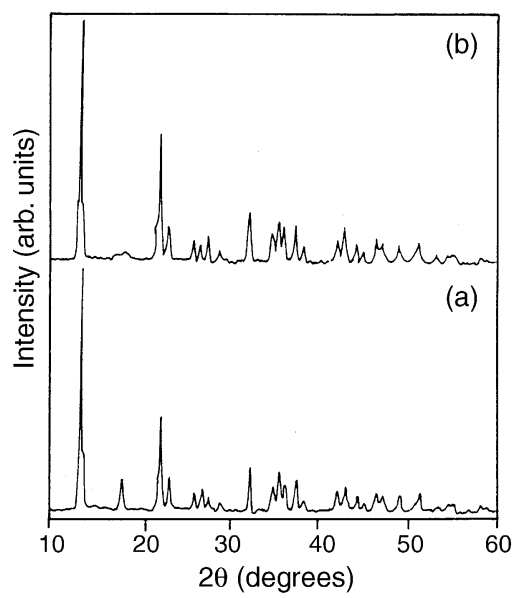

Fig. 5. Powder XRD patterns of $\mathrm{Y}\left(\mathrm{N}_{2} \mathrm{H}_{3} \mathrm{COO}\right)_{3} \cdot 3 \mathrm{H}_{2} \mathrm{O}$ and $\mathrm{Eu}\left(\mathrm{N}_{2} \mathrm{H}_{3}\right.$ $\mathrm{COO})_{3} \cdot 3 \mathrm{H}_{2} \mathrm{O}$. these complexes are very similar to each other and hence, these complexes form solid solution when treated $\mathrm{Eu}^{3+}$ and $\mathrm{Y}^{3+}$ salts with hydrazine carboxylates. Thus, Yttrium (III) chloride and europium (III) chloride were treated with hydrazine carboxylate, $\mathrm{N}_{2} \mathrm{H}_{3} \mathrm{COON}_{2} \mathrm{H}_{5}$ at room temperature. This reaction yields yttrium europium hydrazine carboxylate precursor, $\left(\mathrm{Y}_{0.975} \mathrm{Eu}_{0.025}\right)\left(\mathrm{N}_{2} \mathrm{H}_{3} \mathrm{COO}\right)_{3} \cdot 3 \mathrm{H}_{2} \mathrm{O}$. This compound was decomposed in air in the temperature range $600-1000^{\circ} \mathrm{C}$ to get red phosphor. Or the redox compound was mixed with calculated amount of either ammonium nitrate or ammonium perchlorate and was rapidly heated at $300{ }^{\circ} \mathrm{C}$ to get $\mathrm{Eu}^{3+}$ doped red phosphor [60].

\subsection{Luminescent properties of red phosphors}

\subsection{1. $\mathrm{Eu}^{3+}$ activated oxide red phosphors}

$\mathrm{Y}_{2} \mathrm{O}_{3}$ has two different crystallographic sites $\left(\mathrm{C}_{2}\right.$ and $S_{6}$ ) for $\mathrm{Y}^{3+}$ ion [61]. $\mathrm{C}_{2}$ and $\mathrm{S}_{6}$ sites are present in $3: 1$ ratio. Therefore, $\mathrm{Eu}^{3+}$ has equal probability of occupying $\mathrm{C}_{2}$ and $\mathrm{S}_{6}$ site. Eu ${ }^{3+}$ occupying $\mathrm{C}_{2}$ site shows characteristic red-orange emission (Fig. 6) at $611 \mathrm{~nm}$. This emission at $611 \mathrm{~nm}$ is due to electric dipole transition. It is very sharp and looks like atomic emission. This characteristic emission band is attributed to the electric dipole transition, ${ }^{5} \mathrm{D}_{0} \rightarrow{ }^{7} \mathrm{~F}_{2}$ of the $\mathrm{Eu}^{3+}$ ions [62]. Other transitions of $\mathrm{Eu}^{3+}$ are also seen in the fluorescent spectra but these are very weak. This is usually observed if the product is homogeneous, which

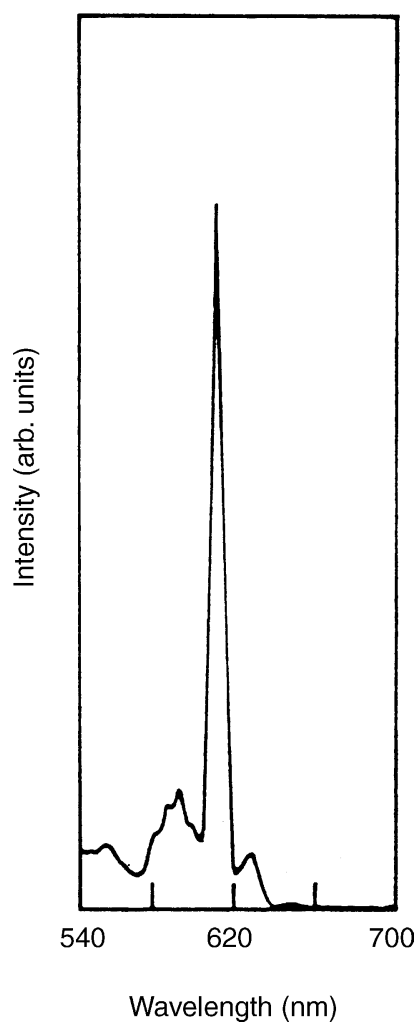

Fig. 6. Emission spectrum of $\mathrm{Y}_{1.95} \mathrm{Eu}_{0.05} \mathrm{O}_{3}$ (ODH process). Excitation wave length was $254 \mathrm{~nm}$. 


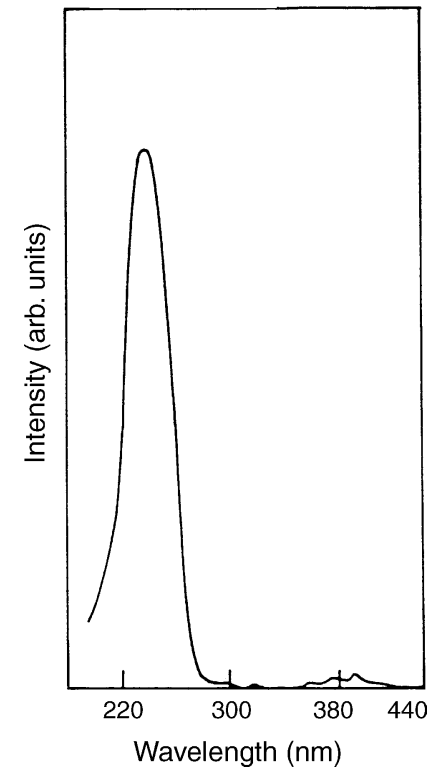

Fig. 7. Excitation spectrum of $\mathrm{Y}_{1.95} \mathrm{Eu}_{0.05} \mathrm{O}_{3}$ (ODH process) when the emission wave length was $611 \mathrm{~nm}$.

favour strong energy transfer from $S_{6}$ to $C_{2}$ [11]. Fig. 7 shows excitation spectrum of $\mathrm{Y}_{2} \mathrm{O}_{3}: \mathrm{Eu}^{3+}$. It shows very broad beak and this peak falls in the region of $254 \mathrm{~nm}$. This excitation peak is due to charge transfer from oxygen to europium (III) ion. Similarly, $\mathrm{Eu}^{3+}$ activated $\mathrm{Gd}_{2} \mathrm{O}_{3}$ was also prepared by solution combustion method using gadolinum nitrate, europium nitrate and oxalyl dihydrazide/urea. Fluorescent spectrum of $\mathrm{Gd}_{2} \mathrm{O}_{3}: \mathrm{Eu}^{3+}$ was very similar to that of $\mathrm{Y}_{2} \mathrm{O}_{3}: \mathrm{Eu}^{3+}$.

\subsubsection{Effect of calcinations on luminescence of $\mathrm{Eu}^{3+}$ red phosphors}

Combustion synthesized red phosphors (ODH process, urea process and precursor method) were calcined at different temperature in order to know the effect of calcinations on their luminescent properties. Calcination does not affect the position of emission wavelengths of all combustion synthesized red phosphors. It indicates that $\mathrm{Eu}^{3+}$ environment is not affected by calcinations. Fig. 8 illustrates the effect of calcinations on emission intensity $(611 \mathrm{~nm})$ of $\mathrm{Y}_{2} \mathrm{O}_{3}: \mathrm{Eu}^{3+}$ and $\mathrm{Gd}_{2} \mathrm{O}_{3}: \mathrm{Eu}^{3+}$ red phosphors. For all the fluorescent experiments, the excitation wave length was kept as $254 \mathrm{~nm}$. $\mathrm{Y}_{2} \mathrm{O}_{3}: \mathrm{Eu}^{3+}$ (ODH process) phosphor shows a slight increase in emission intensity whereas $\mathrm{Y}_{2} \mathrm{O}_{3}: \mathrm{Eu}^{3+}$ (urea process and precursor process) and $\mathrm{Gd}_{2} \mathrm{O}_{3}: \mathrm{Eu}^{3+}$ (ODH process) red phosphors exhibit remarkable increase in emission intensity. The increase in emission intensity is observed in the temperature range $500-800^{\circ} \mathrm{C}$. But, beyond $1000^{\circ} \mathrm{C}$, calcination does not alter the emission intensity significantly. The increase in emission intensity of the combustion synthesized these red phosphors on calcinations may be attributed to improved crystalline.
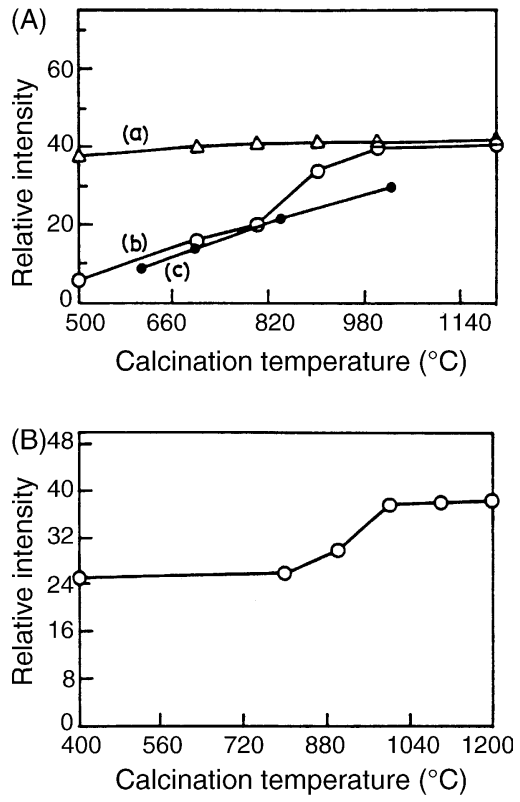

Fig. 8. (A) Effect of calcination on luminescence of $\mathrm{Y}_{2} \mathrm{O}_{3}: \mathrm{Eu}^{3+} \mathrm{Gd}_{2} \mathrm{O}_{3}: \mathrm{Eu}^{3+}$ red phosphors. (a) ODH process, (b) urea process, and (c) from hydrazine carboxylate complex. (B) $\mathrm{Gd}_{2} \mathrm{O}_{3}: \mathrm{Eu}^{3+}(\mathrm{ODH}$ process).

\subsubsection{Effect of impurity ions on luminescence of $\mathrm{Eu}^{3+}$ activated red phosphors}

Impurity ions such as $\mathrm{Ca}^{2+}, \mathrm{Mg}^{2+}, \mathrm{Zn}^{2+}, \mathrm{Ce}^{4+}, \mathrm{Zr}^{4+}, \mathrm{Gd}^{3+}$ $(\sim 2.5 \mathrm{~mol} \%)$ were doped in $\mathrm{Y}_{2} \mathrm{O}_{3}: \mathrm{Eu}^{3+}$ to study their influence on the luminescence of $\mathrm{Eu}^{3+}$. The position of emission wavelengths of $\mathrm{Y}_{2} \mathrm{O}_{3}: \mathrm{Eu}^{3+}$ is not affected by the addition of impurity ions. But, the emission intensity is influenced by the addition of the impurity ions. This indicates that environment around $\mathrm{Eu}^{3+}$ is not influenced by the addition of impurity ions. Table 2 summarizes relative emission intensity of $\mathrm{Eu}^{3+}$ with different impurity ions. Addition of divalent metal ions enhances the emission intensity, whereas tetravalent metal ions decrease the emission intensity. However, trivalent metal ions do not alter the emission intensity significantly.

Since doping of calcia shows appreciable effect, detailed studies on calcia doped $\mathrm{Y}_{2} \mathrm{O}_{3}: \mathrm{Eu}^{3+}$ were carried out. Fig. 9 shows the fluorescence spectra of calcia doped and undoped $\mathrm{Y}_{2} \mathrm{O}_{3}: \mathrm{Eu}^{3+}$ red phosphors. Calcia doped $\mathrm{Y}_{2} \mathrm{O}_{3}: \mathrm{Eu}^{3+}$ shows 10 -fold increase in emission intensity. The enhanced emission intensity of $\mathrm{Eu}^{3+}$ by the addition of $\mathrm{Ca}^{2+}$ may be attributed to reduction of interstitial oxygen [63] (interstitial

Table 2

Effect of impurity ions on luminescence of $\mathrm{Eu}^{3+}$

\begin{tabular}{lc}
\hline Phosphor, $\mathrm{Y}_{1.90} \mathrm{M}_{0.05} \mathrm{Eu}_{0.05} \mathrm{O}_{3}$ & Relative emission intensity of $611 \mathrm{~nm}$ \\
\hline- & 35 \\
$\mathrm{Ca}^{2+}$ & 450 \\
$\mathrm{Mg}^{2+}$ & 420 \\
$\mathrm{Zn}^{2+}$ & 385 \\
$\mathrm{Gd}^{3+}$ & 31 \\
$\mathrm{La}^{3+}$ & 33 \\
$\mathrm{Ce}^{4+}$ & 26 \\
$\mathrm{Zr}^{4+}$ & 28 \\
\hline
\end{tabular}




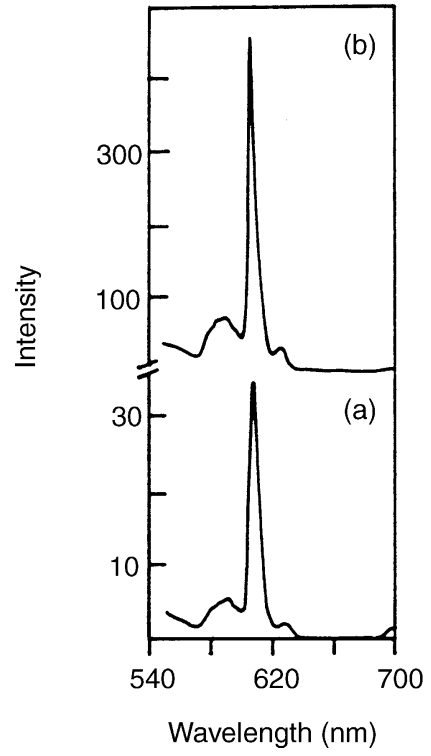

Fig. 9. Fluorescence spectra of $\mathrm{CaO}$ doped and undoped $\mathrm{Y}_{2-x} \mathrm{Ca}_{x} \mathrm{O}_{3}: \mathrm{Eu}^{3+}$ red phosphor (a) $x=0$ and (b) $x=0.05 . \lambda_{\mathrm{exc}}=254 \mathrm{~nm}$.

oxygen absorbs part of the excitation radiation and exhibits no emission). Calcia content was increased in the formula, $\mathrm{Y}_{1.95-x} \mathrm{Ca}_{x} \mathrm{Eu}_{0.05} \mathrm{O}_{3}$ in order to investigate its effect on the luminescent properties of $\mathrm{Eu}^{3+}$. Typical powder XRD patterns of as prepared $\mathrm{Y}_{1.95-x} \mathrm{Ca}_{x} \mathrm{Eu}_{0.05} \mathrm{O}_{3}$ phosphors $(x=0.5$ and $x=0.75$ ) are shown in Fig. 10. It can be seen that up to $x=0.5$, formation of single phase is observed. For $x=0.75$, presence of $\mathrm{CaO}$ is also observed. Fig. 11 shows the plot of calcium content versus relative emission intensity. It reveals that emission intensity is more at the initial calcia addition. Further addition of calcia increases the relative emission intensity slightly up to $x=0.5$. Beyond the value of $x=0.5$, drop in emission intensity is seen in the plot. The decrease in emission intensity may be attributed to the formation of nonluminescent calcia or less luminescence of $\mathrm{Eu}^{3+}$ doped $\mathrm{CaO}$. The presence of calcia was confirmed by the powder XRD pattern of as-prepared phosphor (Fig. 10). Thus, expensive yttrium could be substituted by inexpensive calcium upto 25 mol\% without affecting the luminescence of $\mathrm{Eu}^{3+}$.

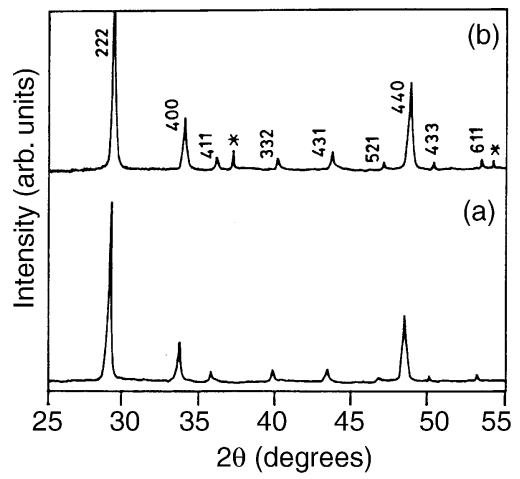

Fig. 10. Powder XRD patterns of as-prepared $\mathrm{Y}_{1.95-x} \mathrm{Ca}_{x} \mathrm{Eu}_{0.05} \mathrm{O}_{3}$ red phosphors (a) $x=0.5$ and (b) $x=0.75$ where $*$ indicates $\mathrm{CaO}$.

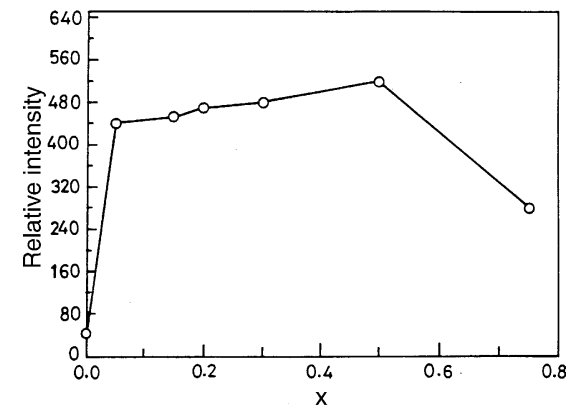

Fig. 11. Plot of calcium content and emission intensity of $\mathrm{Y}_{1.95-x} \mathrm{Ca}_{x} \mathrm{Eu}_{0.05} \mathrm{O}_{3}$ red phosphor.

\subsubsection{Luminescent properties of Eu ${ }^{3+}$ activated borate red phosphors}

The borates of the lighter rare earths (lanthanum to neodymium) possess the aragonite structure: orthorhombic with Pnam as the space group [64]. The lanthanum, occupying the $4 \mathrm{c}$ crystallographic position, has a Cs point site symmetry. The borates of the heavier rare earths (samarium to luetetium) have the vaterite structure with an octahedrally coordinated and 12-coordinated sites for $\mathrm{Ln}^{3+}$ ions in the ratio 2:1, respectively. For the 12-coordinated site, six oxygen neighbours are at shorter distances while the other six oxygens are at longer distances. $\mathrm{Eu}^{3+}$ occupies at the rare-earth ion site and exhibits different luminescent properties.

Fig. 12 shows the fluorescence spectra of $\mathrm{Eu}^{3+}$ doped $\mathrm{LnBO}_{3}(\mathrm{Ln}=\mathrm{La}, \mathrm{Gd}$ and Y $)$. It shows characteristic red orange emission. The emission spectrum of $\mathrm{LaBO}_{3}: \mathrm{Eu}^{3+}$ consists of two bands at 615 and $595 \mathrm{~nm}$ and these bands are attributed to ${ }^{5} \mathrm{D}_{0} \rightarrow{ }^{7} \mathrm{~F}_{2}$ and ${ }^{5} \mathrm{D}_{0} \rightarrow{ }^{7} \mathrm{~F}_{1}$ transition of 9-coordinated $\mathrm{Eu}^{3+}$ ions, respectively. But, there are three bands at 625,610 and $595 \mathrm{~nm}$ observed for $\mathrm{GdBO}_{3}: \mathrm{Eu}^{3+}$ and $\mathrm{YBO}_{3}: \mathrm{Eu}^{3+}$ phosphors. The band at $595 \mathrm{~nm}$ is attributed to magnetic dipole ${ }^{5} \mathrm{D}_{0} \rightarrow{ }^{7} \mathrm{~F}_{1}$ transition of $\mathrm{Eu}^{3+}$, whereas the bands at $625 \mathrm{~nm}$ and $610 \mathrm{~nm}$ are attributed to electric dipole ${ }^{5} \mathrm{D}_{0} \rightarrow{ }^{7} \mathrm{~F}_{2}$ transition for 12 and 8 coordinated $\mathrm{Eu}^{3+}$ ions, respectively. Since electric dipole transition, ${ }^{5} \mathrm{D}_{0} \rightarrow{ }^{7} \mathrm{~F}_{2}$ depends upon the structure, there are two bands observed for different coordinated $\mathrm{Eu}^{3+}$ in $\mathrm{GdBO}_{3}: \mathrm{Eu}^{3+}$ and $\mathrm{YBO}_{3}: \mathrm{Eu}^{3+}$.

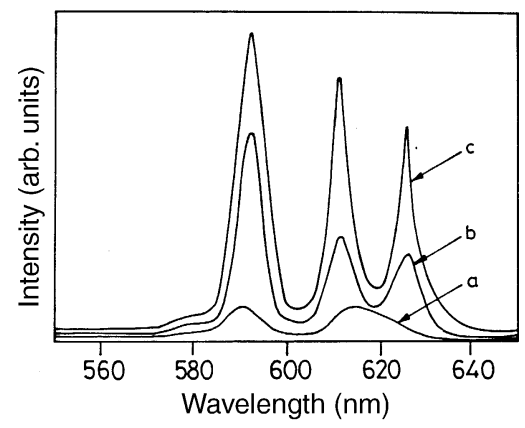

Fig. 12. Fluorescence spectra of $\mathrm{Eu}^{3+}$ activated $\mathrm{LnBO}_{3}: \mathrm{Eu}^{3+}$ red phosphor (a) $\mathrm{Ln}=\mathrm{La}$; (b) $\mathrm{Ln}=\mathrm{Gd}$ and (c) $\mathrm{Ln}=\mathrm{Y}$. Excitation wave length was $254 \mathrm{~nm}$. 


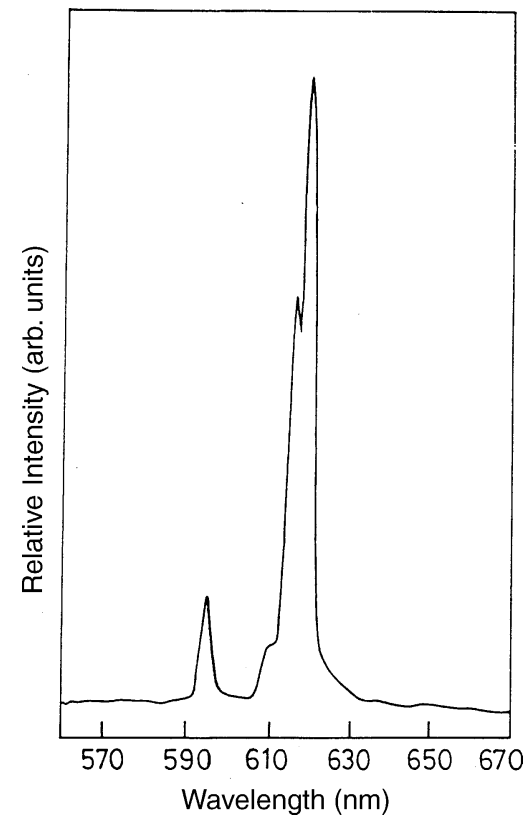

Fig. 13. Fluorescence spectra of $\mathrm{Eu}^{3+}$ activated $\mathrm{YVO}_{4}$ red phosphor (3MP5O process). Excitation wave length was $254 \mathrm{~nm}$.

\subsubsection{Luminescent properties of $\mathrm{Eu}^{3+}$ activated vanadate red phosphors}

Yttrium vanadate is a tetragonal crystal structure having the $\mathrm{ZrSiO}_{4}$ structure and the space group is I41/amd [65]. In this structure the vanadium atoms are tetrahedrally coordinated with oxygen atoms, while yttrium ions are surrounded by eight oxygen neighbours arranged in the form of two distorted tetrahedral. $\mathrm{Eu}^{3+}$ occupies at eight-coordinated $\mathrm{Y}^{3+}$ site in $\mathrm{YVO}_{4}$.

Fluorescence spectrum of $\mathrm{Y}_{0.95} \mathrm{Eu}_{0.05} \mathrm{VO}_{4}$ is shown in Fig. 13. It shows emissions at 595, 611, 615 and $619 \mathrm{~nm}$. The bands at 611,615 and $619 \mathrm{~nm}$ result from ${ }^{5} \mathrm{D}_{0} \geq{ }^{7} \mathrm{~F}_{2}$ transition for $\mathrm{Eu}^{3+}$ ion. The crystal field splitting of the ${ }^{7} \mathrm{~F}_{2}$ level can lead to five distinguishable states, and the transition at 611,615 and $619 \mathrm{~nm}$ differ in regard to the particu$\operatorname{lar}{ }^{7} \mathrm{~F}_{2}$ state on which they terminate [53]. The emission at $595 \mathrm{~nm}$ is due to ${ }^{5} \mathrm{D}_{0} \geq{ }^{7} \mathrm{~F}_{1}$ transition as reported. Fig. 14 shows the plot of relative emission intensity of $\mathrm{YVO}_{4}: \mathrm{Eu}^{3+}$ as a function of calcinations temperature. Emission intensity

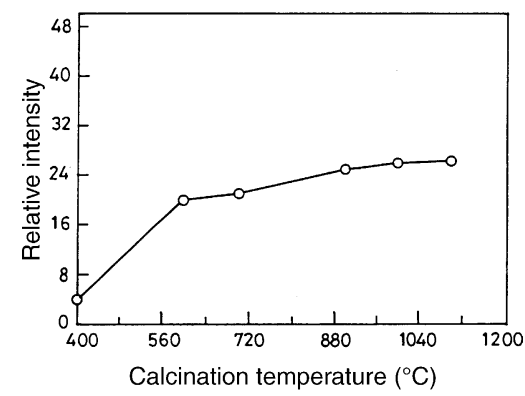

Fig. 14. Plot of relative emission intensity of $\mathrm{YVO}_{4}: \mathrm{Eu}^{3+}$ as a function of calcinations temperature. of $\mathrm{YVO}_{4}: \mathrm{Eu}^{3+}(619 \mathrm{~nm})$ increases in the temperature range $400-600{ }^{\circ} \mathrm{C}$. Then, it increases moderately up to $1000^{\circ} \mathrm{C}$ and remains almost unaffected beyond $1000^{\circ} \mathrm{C}$. Improved crystallanity may be responsible for the increase in the emission intensity with calcinations temperature.

\subsection{Blue phosphors [66]}

The activator used for blue phosphor is $\mathrm{Eu}^{2+}$ and the commonly used hosts are $\mathrm{BaMgAl}_{10} \mathrm{O}_{17}, \mathrm{BaMg}_{2} \mathrm{Al}_{16} \mathrm{O}_{27}$ and $\mathrm{Ba}_{0.64} \mathrm{Al}_{12} \mathrm{O}_{18.64}$.

\subsubsection{Combustion synthesis of $\mathrm{Eu}^{2+}$ activated blue phosphors}

$\mathrm{Eu}^{2+}$ doped barium based compounds were prepared by rapidly heating an aqueous concentrated solution containing stoichiometric amounts of metal nitrates and a fuel (carbohydrazide or diformyl hydrazine or urea) at $400 / 500{ }^{\circ} \mathrm{C}$. Theoretical equation for the formation of $\mathrm{BaMgAl}_{10} \mathrm{O}_{17}: \mathrm{Eu}^{2+}$ and $0.64 \mathrm{BaO} \cdot 6 \mathrm{Al}_{2} \mathrm{O}_{3}: \mathrm{Eu}^{2+}$ from $\mathrm{M}\left(\mathrm{NO}_{3}\right)_{2}(\mathrm{M}=\mathrm{Ba}$ and $\mathrm{Mg})$, $\mathrm{M}\left(\mathrm{NO}_{3}\right)_{3}(\mathrm{M}=\mathrm{Al}$ and $\mathrm{Eu})$ and urea at $500^{\circ} \mathrm{C}$, assuming complete combustion, may be written as

$0.64-x \mathrm{Ba}\left(\mathrm{NO}_{3}\right)_{2}+x \mathrm{Eu}\left(\mathrm{NO}_{3}\right)_{3}+12 \mathrm{Al}\left(\mathrm{NO}_{3}\right)_{3}$

\section{$+23.3 \mathrm{CH}_{6} \mathrm{~N}_{4} \mathrm{O}(\mathrm{CH})$}

$\rightarrow \mathrm{Ba}_{0.64-x} \mathrm{Eu}_{x} \mathrm{Al}_{12} \mathrm{O}_{18.64}(s)+$ by product (blue phosphor)

$1-x \mathrm{Ba}\left(\mathrm{NO}_{3}\right)_{2}+x \mathrm{Eu}\left(\mathrm{NO}_{3}\right)_{3}+\mathrm{Mg}\left(\mathrm{NO}_{3}\right)_{2}+10 \mathrm{Al}\left(\mathrm{NO}_{3}\right)_{3}$

$+28.33 \mathrm{CH}_{4} \mathrm{~N}_{2} \mathrm{O}$ (urea)

$\rightarrow \mathrm{Ba}_{1-x} \mathrm{Eu}_{x} \mathrm{MgAl}_{10} \mathrm{O}_{17}(s)+$ by products (blue phosphor)

Formation of blue phosphors was confirmed by powder XRD. Fig. 15 shows the powder XRD patterns of $\mathrm{Eu}^{2+}$ doped

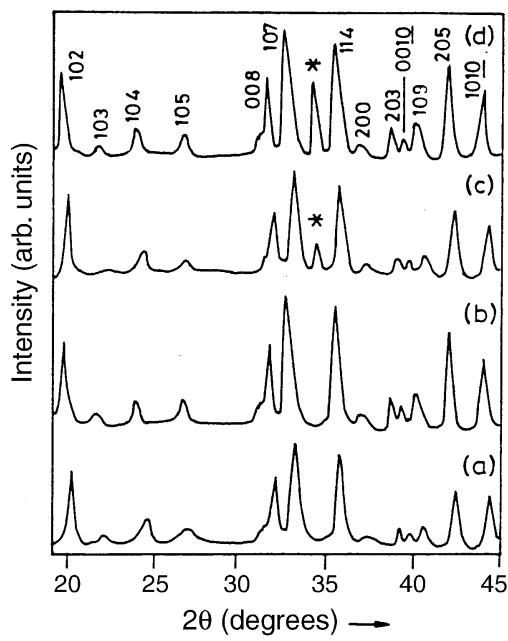

Fig. 15. Powder XRD patterns of $\mathrm{Eu}^{2+}$ doped $x \mathrm{BaO}^{2} 6 \mathrm{Al}_{2} \mathrm{O}_{3}$, (a) $x=0.64$ (b) $x=0.82$; (c) $x=1.00$ and (d) $x=1.3$, where $* \mathrm{BaAl}_{2} \mathrm{O}_{4}$. 
$x \mathrm{BaO} 6 \mathrm{Al}_{2} \mathrm{O}_{3}, x=0.64-1.3$. It is observed that hexa aluminate having barium content lower than 0.82 does not show any additional XRD. When $x>0.82$, additional peaks corresponding to those of $\mathrm{BaAl}_{2} \mathrm{O}_{4}$ are noticed. Quantity of $\mathrm{BaAl}_{2} \mathrm{O}_{4}$ increases with increase of the barium content in barium hexa aluminate. According to Kimura and coworkers [67], coexistence of two phases (barium poor and barium rich) was indicated by the splitting in (107) reflections, whereas according to Smets et al. [68] splittings of ( $\left.\begin{array}{lll}0 & 0 & 1\end{array}\right)$ reflections are more diagnostic indicators of the phase multiplicity. Therefore, selected reflections were recorded under slow scanning mode for high resolution. No splitting was observed in any one of these reflections for the as-prepared as well as calcined $\left(1300{ }^{\circ} \mathrm{C}\right)$ phosphor. These results indicate that the phosphors obtained by the combustion process are monophasic nonstoichiometric hexa aluminate.

\subsubsection{Luminescent properties of $\mathrm{Eu}^{2+}$ activator blue phosphors}

Both $\mathrm{BaMgAl}_{10} \mathrm{O}_{17}$ and $\mathrm{BaAl}_{12} \mathrm{O}_{19}$ are structurally related to hexagonal beta-alumina, $\mathrm{NaAl}_{11} \mathrm{O}_{17}[69,70]$. Beta-alumina is built out of spinel blocks separated by an intermediate layer, which accommodates two large ions $\mathrm{Na}^{+}$ and $\mathrm{O}^{2-}$ per spinel blocks. In this structure when all $\mathrm{Na}^{+}$ ions are replaced by $\mathrm{Ba}^{2+}$ and $\mathrm{Al}^{3+}$ ions are replaced by $\mathrm{Mg}^{2+}$ in the spinel blocks maintaining charge balance to obtain $\mathrm{BaMgAl}_{10} \mathrm{O}_{17}$. But, to get $\mathrm{BaAl}_{12} \mathrm{O}_{19} 75 \%$ of the sodium ions are randomly replaced by $\mathrm{Ba}^{2+}$ and $25 \%$ by $\mathrm{O}^{2-}$ in beta-alumina $\mathrm{NaAl}_{11} \mathrm{O}_{17} \cdot \mathrm{Eu}^{2+}$ occupies at barium site to exhibit blue emission.

Presence of $\mathrm{Eu}^{2+}$ was confirmed by fluorescence spectra. Emission spectra of as-prepared $\mathrm{Eu}^{2+}$ activated $\mathrm{BaMgAl}_{10} \mathrm{O}_{17}, \mathrm{BaMg}_{2} \mathrm{Al}_{16} \mathrm{O}_{27}$ and $\mathrm{Ba}_{0.64} \mathrm{Al}_{12} \mathrm{O}_{18.64}$ show characteristic blue emission at 450, 450 and $435 \mathrm{~nm}$, respectively (Fig. 16). The concentration of $\mathrm{Eu}^{2+}$ in $\mathrm{BaMgAl}_{10} \mathrm{O}_{17}$ was optimised in order to obtain maximum UV stability with minimum concentration quenching. The phosphors with activator concentration ranging from 2 to $20 \mathrm{~mol} \%$ were prepared by the combustion of corresponding metal nitrates and urea at $500{ }^{\circ} \mathrm{C}$. The as-prepared phosphors showed single phase crystalline nature. The room temperature fluorescence spectra of all the phosphors were recorded under the same condition by exciting at $254 \mathrm{~nm}$ and the relative emission intensity was monitored. It revealed that relative emission intensity increased with increasing activator concentration. Above the $16 \mathrm{~mol} \%$ activator concentration, sudden drop in relative emission intensity was observed and it is probably due to concentration quenching. Hence, $16 \mathrm{~mol} \%$ was found to be the optimum concentration of activator for maximum emission intensity.

Fig. 17 shows emission spectra of $\mathrm{Eu}^{2+}$ doped $x \mathrm{BaO} 6 \mathrm{Al}_{2} \mathrm{O}_{3} \quad(0.64<x>1.3)$. All the phosphors show characteristic emission in blue region $(435-462 \mathrm{~nm})$. This emission band is attributed to $\mathrm{Eu}^{2+} 4 \mathrm{f}^{6} 5 \mathrm{~d} \rightarrow 4 \mathrm{f}^{7}$ transition. It is noticed that with increase in barium content the

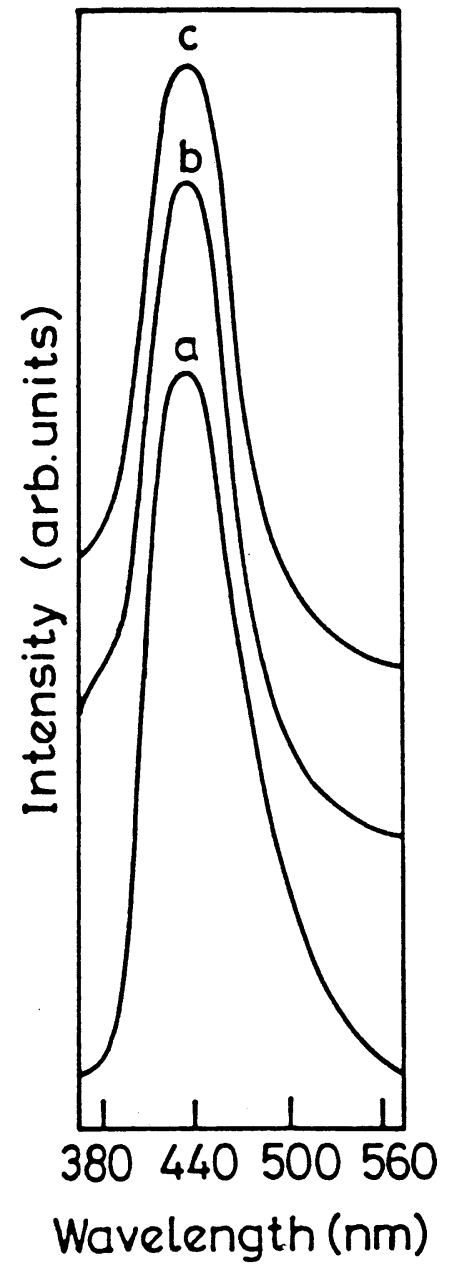

Fig. 16. Emisssion spectra of $\mathrm{Eu}^{2+}$ activated (a) $\mathrm{BaMgAl}_{10} \mathrm{O}_{17}$, (b) $\mathrm{BaMg}_{2} \mathrm{Al}_{16} \mathrm{O}_{27}$ and (c) $\mathrm{Ba}_{0.64} \mathrm{Al}_{12} \mathrm{O}_{18.64}$ blue phosphors (urea process). Excitation wave length was $254 \mathrm{~nm}$.

emission band shifts towards longer wavelength. The shift in emission band towards longer wavelength at higher barium concentration may be attributed to formation of $\mathrm{Eu}^{2+}$ doped $\mathrm{BaAl}_{2} \mathrm{O}_{4}$. It has been reported that $\mathrm{Eu}^{2+}$ doped barium aluminate $\left(\mathrm{BaAl}_{2} \mathrm{O}_{4}\right)$ shows emission band at $505 \mathrm{~nm}$ [71]. This observation is confirmed by the powder XRD (Fig. 15), which shows the presence of $\mathrm{BaAl}_{2} \mathrm{O}_{4}$ in the barium rich compositions. Since solution combustion process involve atomic level homogeneity of starting materials, doping of $\mathrm{Eu}^{2+}$ takes place at barium site in both barium hexa aluminate and barium aluminate spinel.

\subsection{Green phosphors [72]}

$\mathrm{Tb}^{3+}$ is commonly used as activator for the green emission. The oxide host employed for $\mathrm{Tb}^{3+}$ green emission is $(\mathrm{La}, \mathrm{Ce}) \mathrm{MgAl}_{11} \mathrm{O}_{19}$. Other possible green phosphors for fluorescent lamps are $(\mathrm{Ce}, \mathrm{Gd}) \mathrm{MgB}_{5} \mathrm{O}_{10}: \mathrm{Tb}^{3+}$ and (La,Ce) $\mathrm{PO}_{4}: \mathrm{Tb}^{3+}$. 


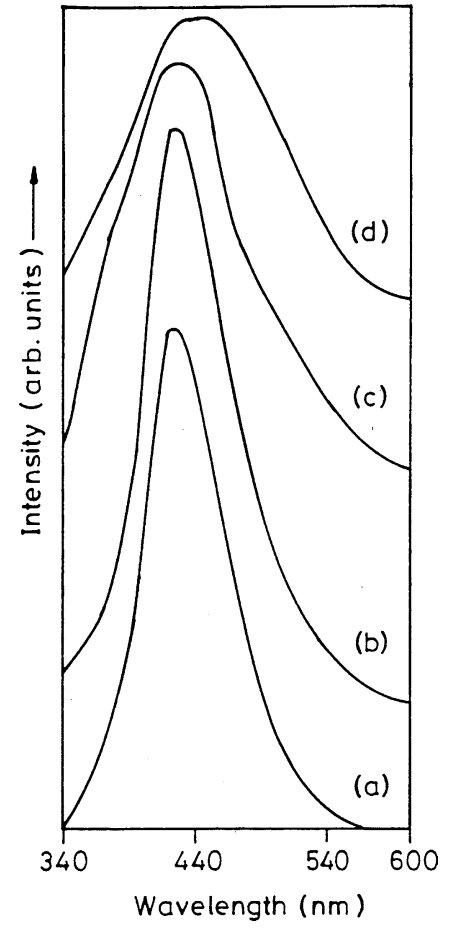

Fig. 17. Emission spectra of $\mathrm{Eu}^{2+}$ doped $x \mathrm{BaO}^{2} 6 \mathrm{Al}_{2} \mathrm{O}_{3}$ (a) $x=0.64$; (b) $x=0.82$; (c) $x=1.0$ and (d) $x=1.3$. Excitation wave length was $254 \mathrm{~nm}$.

\subsubsection{Combustion synthesis of $\mathrm{Tb}^{3+}$ activated green phosphor}

$\mathrm{Tb}^{3+}$ activated $(\mathrm{La}, \mathrm{Ce}) \mathrm{MgAl}_{11} \mathrm{O}_{19}$ green phosphor was obtained by rapidly heating an aqueous concentrated solution containing stoichiometric amounts of metal nitrates $\left(\mathrm{La}\left(\mathrm{NO}_{3}\right)_{3}, \mathrm{Ce}\left(\mathrm{NO}_{3}\right)_{3}, \mathrm{~Tb}\left(\mathrm{NO}_{3}\right)_{3}, \mathrm{Mg}\left(\mathrm{NO}_{3}\right)_{2}\right)$ and urea/diformyl hydrazine redox mixture at $500{ }^{\circ} \mathrm{C}$. The stoichiometric composition of the redox mixtures for the combustion was calculated using the total oxidizing $(\mathrm{O})$ and reducing (F) valencies. Thus, $\mathrm{M}\left(\mathrm{NO}_{3}\right)_{2}$ :urea (1:1.66), $\mathrm{M}\left(\mathrm{NO}_{3}\right)_{3}$ :urea (1:2.5), $\mathrm{M}\left(\mathrm{NO}_{3}\right)_{2}$ :DFH (1:1.25) and $\mathrm{M}\left(\mathrm{NO}_{3}\right)_{3}: \mathrm{DFH}(1: 1.88)$ redox compositions were used for combustion. Theoretical equation assuming complete combustion can be written as follows.

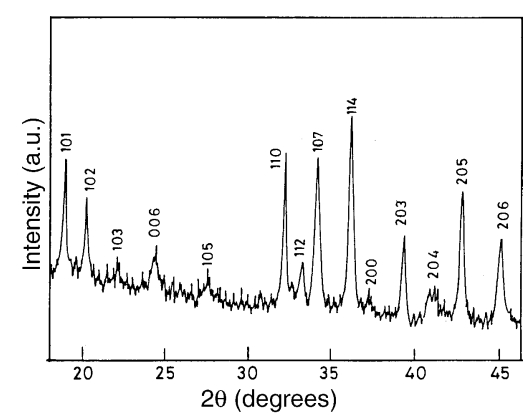

Fig. 18. Powder XRD pattern of $\left(\mathrm{La}_{0.15} \mathrm{Ce}_{0.5} \mathrm{~Tb}_{0.35}\right) \mathrm{MgAl}_{11} \mathrm{O}_{19}$ (urea process).

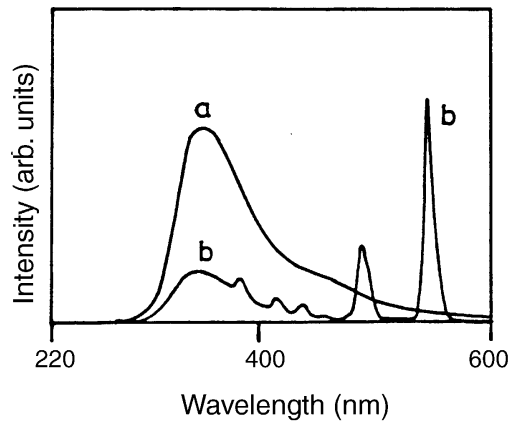

Fig. 19. Emission spectrum of (a) $\left(\mathrm{La}_{0.98} \mathrm{Ce}_{0.02}\right) \mathrm{MgAl}_{11} \mathrm{O}_{19}$, (b) $\left(\mathrm{La}_{0.98} \mathrm{Ce}_{0.02}\right) \mathrm{MgAl}_{11} \mathrm{O}_{19}: \mathrm{Tb}^{3+}$. Excitation wave length was $254 \mathrm{~nm}$.

$$
\begin{aligned}
& 1-x \mathrm{Ce}\left(\mathrm{NO}_{3}\right)_{3}+x \mathrm{~Tb}\left(\mathrm{NO}_{3}\right)_{3}+\mathrm{Mg}\left(\mathrm{NO}_{3}\right)_{2}+11 \mathrm{Al}\left(\mathrm{NO}_{3}\right)_{3} \\
& +31.67 \mathrm{CH}_{4} \mathrm{~N}_{2} \mathrm{O} \text { (urea) } \\
& \rightarrow \underset{\text { (green phosphor) }}{\mathrm{Ce}_{1-x} \mathrm{~Tb}_{x} \mathrm{MgAl}_{11} \mathrm{O}_{19}(s)+\text { by product }}
\end{aligned}
$$

Fig. 18 shows the powder XRD pattern of $\mathrm{LaMgAl}_{11} \mathrm{O}_{19}$, which reveals single phase crystalline nature. This observation is notable because conventional ceramic synthesis of $\mathrm{LaMgAl} l_{11} \mathrm{O}_{19}$ requires elevated temperature $\left(>1400^{\circ} \mathrm{C}\right)$ and always contains $\mathrm{Al}_{2} \mathrm{O}_{3}$ as impurity [59].

\subsubsection{Luminescent properties of $\mathrm{Tb}^{3+}$ activated green phosphors}

$\mathrm{LaMgAl}_{11} \mathrm{O}_{19}$ is having a true magnetoplumbite-like structure similar to hexagonal rare-earth aluminates [73]. This structure is related to the structure of the betal-aluminas. It consists of spinel blocks separated by an intermediate layer containing three oxygen, one rare-earth, and one aluminium ion per spinel blocks. The $\mathrm{Mg}^{2+}$ ions are accommodated into the spinel blocks as in $\mathrm{BaMgAl}_{10} \mathrm{O}_{17}$.

Emission spectrum of combustion synthesized $\left(\mathrm{La}_{0.98} \mathrm{Ce}_{0.02}\right) \mathrm{MgAl}_{11} \mathrm{O}_{19}$ shows a broad band at $340 \mathrm{~nm}$ (Fig. 19a). The emission of $\mathrm{Ce}^{3+}$ is due to $4 \mathrm{f}^{6} 5 \mathrm{~d} \rightarrow{ }^{2} \mathrm{~F}_{\mathrm{j}}$ (with $\mathrm{j}=5 / 2$ and $7 / 2$ ) transition. Addition of $\mathrm{Tb}^{3+}$ in $\left(\mathrm{La}_{0.98} \mathrm{Ce}_{0.02}\right) \mathrm{MgAl}_{11} \mathrm{O}_{19}$ resulted in emissions at 480 and $543 \mathrm{~nm}$ in addition to $\mathrm{Ce}^{3+}$ emission (Fig. 19b). The $\mathrm{Tb}^{3+}$ emissions, which arise due to energy transfer from $\mathrm{Ce}^{3+}$, are attributed to ${ }^{5} \mathrm{D}_{3} \rightarrow{ }^{7} \mathrm{~F}_{5}$ and ${ }^{5} \mathrm{D}_{4} \rightarrow{ }^{7} \mathrm{~F}_{5}$ transitions. In order to minimize the ultraviolet $\mathrm{Ce}^{3+}$ emission $(340 \mathrm{~nm}), \mathrm{Tb}^{3+}$ concentration was increased in the formula, $\left(\mathrm{La}_{0.98-x} \mathrm{~Tb}_{x} \mathrm{Ce}_{0.02}\right) \mathrm{MgAl}_{11} \mathrm{O}_{19}$. Fig. 20 illustrates the effect of terbium concentration on the luminescence of $\mathrm{Ce}^{3+}$ and $\mathrm{Tb}^{3+}$ in $\mathrm{LaMgAl}_{11} \mathrm{O}_{19}$ when the excitation wavelength was $254 \mathrm{~nm}$. With the increase in $\mathrm{Tb}^{3+}$ concentration, emission intensity of $\mathrm{Tb}^{3+}$ increases at the expense of $\mathrm{Ce}^{3+}$ emission intensity. This observation may be attributed to increased availability of $\mathrm{Tb}^{3+}$ for absorbing the $\mathrm{Ce}^{3+}$ emission. The $\mathrm{Tb}^{3+}$ emission intensity increases up to $x=0.35$ and beyond the value of $x=0.35$, there is a drop in emission intensity of $\mathrm{Tb}^{3+}$. But, ultraviolet $\mathrm{Ce}^{3+}$ emission continues to decrease with increasing $\mathrm{Tb}^{3+}$ concentration. 
Table 3

Luminescent properties of $\mathrm{LaMgAl}_{11} \mathrm{O}_{19}: \mathrm{Ce}^{3+}, \mathrm{Tb}^{3+}, \mathrm{Eu}^{2+}$

\begin{tabular}{|c|c|c|c|}
\hline \multirow[t]{2}{*}{ Phosphors } & \multicolumn{3}{|c|}{ Emission wavelength ${ }^{\#}, \mathrm{~nm}$} \\
\hline & $\mathrm{Eu}^{2+}$ & $\mathrm{Ce}^{3+}$ & $\mathrm{Tb}^{3+}$ \\
\hline $\mathrm{LaMgAl}_{11} \mathrm{O}_{19}: \mathrm{Ce}^{3+}(10)$ & - & $349(738)$ & - \\
\hline $\mathrm{LaMgAl}_{11} \mathrm{O}_{19}: \mathrm{Eu}^{2+}(5)$ & $442(714)$ & & \\
\hline $\mathrm{LaMgAl}_{11} \mathrm{O}_{19}: \mathrm{Ce}^{3+}(10), \mathrm{Eu}^{2+}(5)$ & $442(1277)$ & $351(320)$ & - \\
\hline $\mathrm{LaMgAl}_{11} \mathrm{O}_{19}: \mathrm{Tb}^{3+}(8), \mathrm{Eu}^{2+}(5)$ & $441(310)$ & - & $542(202)$ \\
\hline $\mathrm{LaMgAl}_{11} \mathrm{O}_{19}: \mathrm{Ce}^{3+}(10), \mathrm{Tb}^{3+}(8), \mathrm{Eu}^{2+}(5)$ & $437(615)$ & $354(68)$ & $542(457)$ \\
\hline
\end{tabular}

\# Excitation wavelength $=254 \mathrm{~nm}$; Parentheses = Intensity.

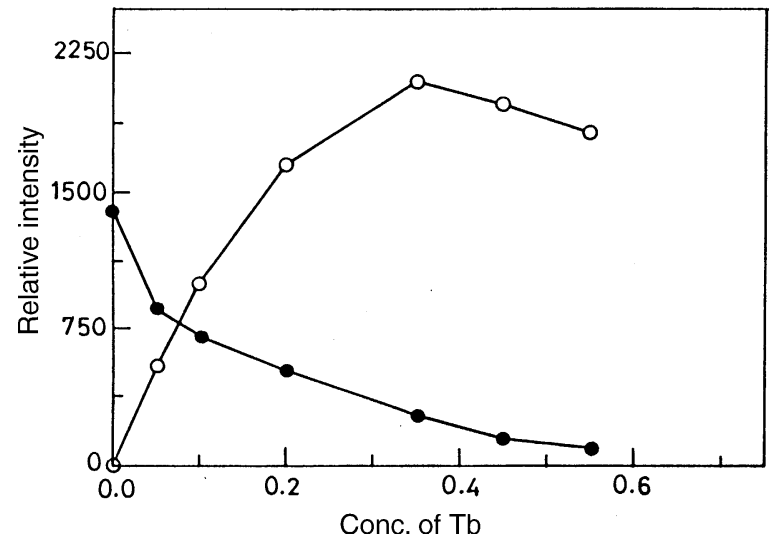

Fig. 20. Plot of emission intensities of $\mathrm{Ce}^{3+}$ and $\mathrm{Tb}^{3+}$ with concentration of $\mathrm{Tb}^{3+}$ in $\left(\mathrm{La}_{0.98-x} \mathrm{~Tb}_{x} \mathrm{Ce}_{0.02}\right) \mathrm{MgAl}_{11} \mathrm{O}_{19}$ green phosphors. $(\bigcirc) \mathrm{Tb}^{3+}$ emission, $(\bigcirc) \mathrm{Ce}^{3+}$ emission.

The decrease in emission intensity of $\mathrm{Tb}^{3+}(x>0.35)$ may be attributed to concentration quenching. Fig. 21 shows the plot of cerium concentration versus emission intensities of $\mathrm{Ce}^{3+}$ and $\mathrm{Tb}^{3+}$ in $\left(\mathrm{La}_{0.63-x} \mathrm{~Tb}_{0.35} \mathrm{Ce}_{x}\right) \mathrm{MgAl}_{11} \mathrm{O}_{19}$. It reveals that with increase in $\mathrm{Ce}^{3+}$ concentration, $\mathrm{Tb}^{3+}$ emission also increases, whereas $\mathrm{Ce}^{3+}$ emission intensity decreases. For the value of $x>0.3$, emission intensity of $\mathrm{Tb}^{3+}$ remains unchanged. But, emission intensity of $\mathrm{Ce}^{3+}$ decreases. Therefore, maximum $\mathrm{Tb}^{3+}$ emission is observed for $\left(\mathrm{La}_{0.15} \mathrm{Ce}_{0.5} \mathrm{~Tb}_{0.35}\right) \mathrm{MgAl}_{11} \mathrm{O}_{19}$ green phosphor. Substitution of $\mathrm{La}^{3+}$ by $\mathrm{Gd}^{3+}$ in the green phosphor does not affect the luminescence of $\mathrm{Tb}^{3+}$. But, substitution of $\mathrm{La}^{3+}$ by $\mathrm{Sm}^{3+}$ quenched $\mathrm{Tb}^{3+}$ emission.

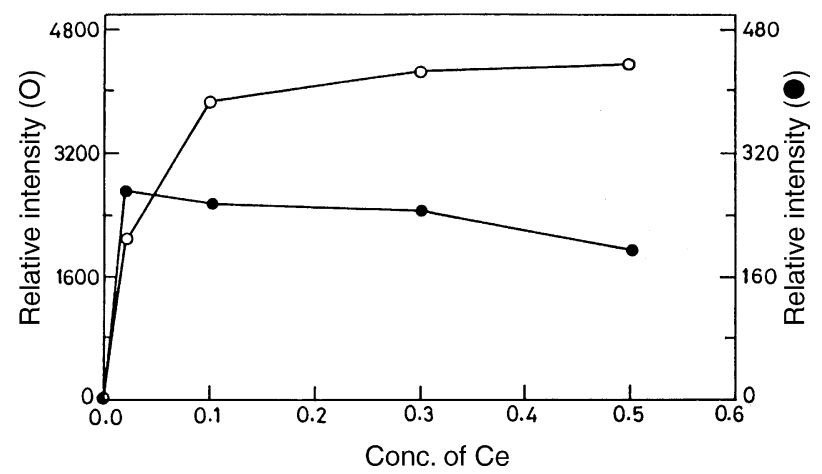

Fig. 21. Plot of emission intensities of $\mathrm{Ce}^{3+}$ and $\mathrm{Tb}^{3+}$ with concentration of $\mathrm{Ce}^{3+}$ in $\left(\mathrm{La}_{0.63-x} \mathrm{Ce}_{x} \mathrm{~Tb}_{0.35}\right) \mathrm{MgAl}_{11} \mathrm{O}_{19}$ green phosphor.
Since $\mathrm{LaMgAl}_{11} \mathrm{O}_{19}$ can also be a host for $\mathrm{Eu}^{2+}$, investigations were carried out to study the effect of simultaneous doping of $\mathrm{Ce}^{3+}, \mathrm{Tb}^{3+}$ and $\mathrm{Eu}^{2+}$ in $\mathrm{LaMgAl}_{11} \mathrm{O}_{19}$. The luminescence properties of these ions are summarized in Table 3 . The results indicate that the addition of $\mathrm{Ce}^{3+}$ enhances $\mathrm{Eu}^{2+}$ emission with a decrease in emission intensity of $\mathrm{Ce}^{3+}$. Where as the addition of $\mathrm{Tb}^{3+}$ decreases the $\mathrm{Eu}^{2+}$ emission intensity. Hence, $\mathrm{Eu}^{2+}$ can also be used as a sensitizer for $\mathrm{Tb}^{3+}$. Unlike $\mathrm{Ce}^{3+}, \mathrm{Eu}^{2+}$ sensitizer does not emit in the ultraviolet region. However, $\mathrm{Tb}^{3+}$ emission intensity is greater when $\mathrm{Ce}^{3+}$ is used as a sensitizer. The increase in the $\mathrm{Eu}^{2+}$ emission may be due to non-radiative energy transfer from $\mathrm{Ce}^{3+}$ to $\mathrm{Eu}^{2+}$. Co-doping of all the activators resulted in emission at 437 $\left(\mathrm{Eu}^{2+}\right), 354\left(\mathrm{Ce}^{3+}\right)$, and 490 and $542 \mathrm{~nm}\left(\mathrm{~Tb}^{3+}\right)$.

\section{Conclusions}

Rare earth doped lamp phosphors obtained by versatile solution combustion process are single phase in nature except $\mathrm{Gd}_{2} \mathrm{O}_{3}: \mathrm{Eu}^{3+}, \mathrm{GdBO}_{3}: \mathrm{Eu}^{3+}$ and $\mathrm{YVO}_{4}: \mathrm{Eu}^{3+}$. The formation of homogeneous single phase lamp phosphors not only demonstrates the capability of the combustion process in the atomic level doping of impurity ions in the host lattices but also confirms the highly exothermic nature of combustion. The major advantages of the combustion process are improvement in processing time, energy saving and the fine particle nature of the combustion products.

\section{References}

[1] G. Blasse, B.C. Grabmair, Luminescent Materials, Springer Verlag, Berlin, 1994.

[2] T. Welker, J. Lumin. $48 / 49$ (1991) 49.

[3] G. Blasse, J. Alloys Compd. 192 (1993) 17.

[4] Proceedings of the 2nd International Conference on f-element, J. Alloys Compd., 1995, pp. 225.

[5] The First International Conference on the Science and Technology of Emissive Displays and Lighting, 12-14 November 2001, San Diego, CA, USA.

[6] Phosphor Global Summit, Scottsdale, AZ, USA, 19-21 March 2003.

[7] Phosphor Global Summit, Marriott Biscane Bay, Miami, FL, USA, 16-18 March 2004.

[8] Proceedings of the International Conference Rare earths' 92, J. Alloys Compd., Kyoto, 1993, pp. 192. 
[9] F. Laville, D. Gourier, A.M. Lejus, D. Vivien, J. Solid State Chem. 49 (1983) 180.

[10] K.A. Wickersheim, R.A. Lefever, J. Electrochem. Soc. 111 (1964) 47.

[11] R.C. Ropp, J. Electrochem. Soc. 111 (1964) 311.

[12] N.C. Chang, J. Appl. Phys. 34 (1963) 3500.

[13] R.B. Hunt Jr., R.G. Pappalardo, J. Lumin. 34 (1985) 133.

[14] P. Maestro, D. Huguenin, A. Seigneurin, P. Deneuve, P. Le Lann, J.F. Berar, J. Electrochem. Soc. 139 (1992) 1479.

[15] M. Buijs, A. Meijerink, G. Blasse, J. Lumin. 37 (1987) 9.

[16] D.B.M. Klaasen, R.A.M. van Ham, T.G.M. van Rijn, J. Lumin. 43 (1989) 261

[17] R.G. Pappalardo, R.B. Hunt Jr., J. Electrochem. Soc. 132 (1985) 721.

[18] L.H. Brixner, E. Abramson, J. Electrochem. Soc. 112 (1965) 70.

[19] F. Laville, M. Perrin, A.M. Lejus, M. Gasperin, R. Moncorge, D. Vivien, J. Solid State Chem. 65 (1986) 301.

[20] H.T. Hintzen, H.M. van Noort, J. Phys. Chem. Solids 49 (1988) 873.

[21] F.C. Palilla, A.K. Levine, M. Rinkevics, J. Electrochem. Soc. 112 (1965) 776.

[22] E. Antic-Fidancev, M. Lemaitre-Blaise, J. Chaminade, P. Porcher, J. Alloys Compd. 180 (1992) 223.

[23] J. Systma, A. Meijer, G. Blasse, J. Solid State Chem. 99 (1992) 78.

[24] G. Blasse, A. Bril, Philips Tech. Rev. 31 (1970) 303.

[25] G. Blasse, Chem. Mater. 1 (1989) 294.

[26] B.M.J. Smets, Mater. Chem. Phys. 16 (1987) 283.

[27] G. Blasse, Chem. Mater. 6 (1994) 1465.

[28] S.L. Issler, C.C. Torardi, J. Alloys Compd. 229 (1995) 54.

[29] C.R. Ronda, J. Alloys Compd. 225 (1995) 534

[30] G. Blasse, J. Alloys Compd. 225 (1995) 529.

[31] P. Maestro, D. Huguenin, J. Alloys Compd. 225 (1995) 520.

[32] E. Banks, J. Electrochem. Soc. 125 (1978) 415C.

[33] C.R. Ronda, T. Justel, H. Nikol, J. Alloys Compd. 275-277 (1998) 669.

[34] T. Justel, H. Nikol, C. Ronda, Angew. Chem. Int. Ed. 37 (1998) 3084.

[35] R.C. Ropp, Luminescence and the Solid State, Elsevier Science, Amsterdam, 1991.

[36] P. Wacher, D.J. Bracco, F.C. Palilla, Electrochem. Technol. 5 (1967) 358.

[37] R.E. Newnham, M.J. Redman, R.P. Santoro, J. Am. Chem. Soc. 46 (1963) 253.

[38] J.M.P.J. Verstegen, J.L. Sommerdijk, J.G. Verriet, J. Lumin. 6 (1973) 425.

[39] A.G. Avanesov, K.B. Achmiz, P.I. Bykovskii, Yu.A. Kuzenetsov, V.F. Pisarenko, N.G. Chernaya, Inorg. Mater. 17 (1981) 579.
[40] B.M.J. Smets, J.G. Verlijsdonk, Mater. Res. Bull. 21 (1986) 1305.

[41] J.M.P.J. Verstegen, A.L.N. Stevel, J. Lumin. 9 (1974) 406.

[42] C.R. Ronda, B.M.J. Smets, J. Electrochem. Soc. 136 (1989) 570.

[43] B. Smets, J. Rutten, G. Hocks, J. Verlijsdon, J. Electrochem. Soc. 136 (1989) 2119.

[44] R. Jagannathan, R.P. Rao, T.R.N. Kutty, Mater. Res. Bull. 27 (1992) 459.

[45] C.N.R. Rao, Chemical Approaches to the Synthesis of Inorganic Materials, Wiley, New Delhi, 1994.

[46] K.G. Broadhead, H.H. Heady, Anal. Chem. 32 (1960) 603.

[47] D.W. Johnson Jr., Ceram. Bull. 60 (1981) 221.

[48] S. Erdei, R. Roy, G. Harshe, H. Juwhari, D. Agarwal, F.W. Ainger, W.B. White, Mater. Res. Bull. 30 (1995) 745.

[49] R.P. Rao, Solid State Commun. 99 (1996) 439.

[50] M.L.F. Phillips, Soc. Photo-Opt. Indust. Eng. 2408 (1995) 200.

[51] R. Roy, D.M. Roy, T.P. O’Holleran, Powder Metal. Intl. 16 (1984) 274.

[52] M.H. Lee, S.G. Oh, S.C. Yi, J. Colloid Interface Sci. 226 (2000) 65.

[53] T. Hirai, Y. Asada, I. Komasawa, J. Colloid Interface Sci. 276 (2004) 339 .

[54] P.K. Sharma, M.H. Jilavi, R. Nass, H. Schmidt, J. Lumin. 82 (1999) 187.

[55] J.J. Kingsley, K.C. Patil, Mater. Lett. 6 (1988) 427.

[56] K.C. Patil, S.T. Aruna, S. Ekambaram, Curr. Opin. Solid State Mater. Sci. 2 (1997) 158

[57] S. Ekambaram, K.C. Patil, Bull. Mater. Sci. 18 (1995) 921.

[58] S. Ekambaram, K.C. Patil, J. Alloys Compd. 217 (1995) 104.

[59] S.S. Trond, J.S. Martin, J.P. Stavanage, A.L. Smith, J. Electrochem. Soc. 116 (1969) 1047.

[60] S. Ekambaram, K.C. Patil, J. Mater. Chem. 5 (1995) 905.

[61] M. Faucher, J. Pannetier, Acta Crystallogr. B36 (1980) 3209.

[62] G. Blasse, A. Bril, W.C. Nieuwpoort, J. Phys. Chem. Solids 27 (1966) 1587.

[63] W. van Schaik, G. Blasse, Chem. Mater. 4 (1992) 410.

[64] A.K. Levine, F.C. Palilla, Electrochem. Technol. 4 (1966) 16.

[65] J.A. Baglio, G. Gashurov, Acta Cryst. B24 (1968) 292.

[66] S. Ekambaram, K.C. Patil, J. Alloys Compd. 248 (1997) 7.

[67] S. Kimura, E. Bannai, I. Shindo, Mater. Res. Bull. 17 (1982) 209.

[68] B. Smets, J. Rutten, J. Hoeks, Verlijsdank, J. Electrochem. Soc. 136 (1989) 2119

[69] A.L.N. Stevel, J. Lumin. 17 (1978) 12.

[70] F.P.F. van Berkel, H.W. Zandbergen, G.C. Verschoor, D.W. Ijdos, Acta Cryst. C40 (1984) 1124.

[71] G. Blasse, A. Brill, Philips Res. Repts. 23 (1968) 201.

[72] S. Ekambaram, K.C. Patil, J. Mater. Synth. Process. 4 (1996) 337.

[73] M. Gasperin, M.C. Saine, A. Kahn, F. Laville, A. Lejus, J. Solid State Chem. 54 (1984) 61. 